\title{
Are maternal metabolic syndrome and lipid profile associated with preterm delivery and preterm premature rupture of membranes?
}

Lida Moghaddam-Banaem ( $\sim$ moghaddamb@modares.ac.ir)

https://orcid.org/0000-0002-9849-7451

\section{Shiva Niyaty}

Tarbiat Modares University Faculty of Medical Sciences

Hadis Sourinejad

Tarbiat Modares University Faculty of Medical Sciences

\section{Samira Mokhlesi}

Islamic Azad University

Research article

Keywords: Metabolic Syndrome, Lipid Profile, Pregnancy, Preterm Delivery, Preterm Premature Rupture of Membranes

Posted Date: September 27th, 2019

DOI: https://doi.org/10.21203/rs.2.15292/v1

License: (c) (i) This work is licensed under a Creative Commons Attribution 4.0 International License. Read Full License 


\section{Abstract}

Objectives We aimed to evaluate the association of metabolic syndrome (MetS), its components and lipid profile in mid-pregnancy with preterm delivery and preterm premature rupture of membranes (PPROM).

Methods This prospective cohort study was conducted on 203 pregnant women between 24-28 weeks of gestation, undergoing the gestational diabetes screening test with $50 \mathrm{gr}$ glucose challenge test (GCT). Fasting serum total cholesterol, low-density lipoprotein cholesterol (LDL-C), high -density lipoprotein cholesterol (HDL-C), and triglyceride (TG) levels were measured during the week after GCT assessment. Information on the participants' pre-pregnancy weight, demographic/ reproductive characteristics, and height and blood pressure (BP) measurements were documented at baseline entry into the study. Metabolic syndrome was defined as the co-existence of 3 or more of the following criteria: Body mass index (BMI) before pregnancy $\geq 30 \mathrm{~kg} / \mathrm{m} 2, \mathrm{BP} \geq 130 / 85 \mathrm{mmHg}, \mathrm{GCT} \geq 140 \mathrm{mg} / \mathrm{dl}, \mathrm{TG} \geq 150 \mathrm{mg} / \mathrm{dl}$, and HDL$\mathrm{C} \leq 50 \mathrm{mg} / \mathrm{dl}$. All participants were followed through routine prenatal care, up to delivery. Any deliveries or rupture of membranes of less than or equal to weeks of pregnancy, were considered preterm delivery and PPROM respectively. Statistical analysis was performed by SPSS V.20, and p-value of less than 0.05 was considered significant.

Results MetS was detected in 10 (4.9\%) of participants. Logistic regression analysis showed HDL-C levels, and hypertension had significant effects on preterm delivery occurrence [(OR: $0.952,95 \% \mathrm{Cl}$ : 0.910_0.995), (OR: 1.629, 95\% Cl: 1.554_1.709) respectively], but no statistically significant results were found for PPROM.

Conclusions Low HDL-C levels and hypertension in mid-pregnancy may increase the occurrence of preterm deliveries, indicating that MetS and its components should be monitored more closely in pregnancy.

\section{Introduction}

In 1998, the World Health Organization (WHO) defined 'metabolic syndrome' (MetS) as a combination of central abdominal (visceral) obesity, glucose intolerance, insulin resistance, dyslipidemia and hypertension (1). This syndrome is a cluster of physiological abnormalities that accelerate the risk of type 2 diabetes and atherosclerotic cardiovascular disease (2). Recently, the diagnostic criteria and etiology of this syndrome have become a controversial topic (3) and its prevalence is a challenging issue worldwide (4). According to one study, the prevalence of metabolic syndrome was considerably higher in Iranian women (55.0\%), and men (30.1\%), than in French women (6.6\%) and men (13.7\%) (5).

Despite the increasing prevalence of MetS worldwide in recent years, and consequently an increased prevalence during pregnancy, there is still no established definition for metabolic syndrome in pregnancy (6). 
Normal pregnancy is associated with varying degrees of resistance to insulin, dyslipidemia, and inflammatory $(7,8)$. Studies that have assessed metabolic components in pregnancy have generally used accepted definitions for the adult population (9).

A preterm birth, described as birth at or under 37 weeks of gestation, can lead to adverse consequences for the newborn (10). Although management of preterm infants has much improved, the mortality and

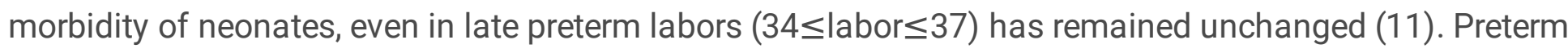
premature rupture of membrane (PPROM) is defined as the rupture of membranes in less than or equal to 37 weeks of gestation and usually leads to preterm birth. This condition affects approximately $3 \%$ of all pregnancies and occurs in up to $30 \%$ of preterm deliveries (12).

In some studies, it has been shown that mothers who have given birth to premature babies suffer from cardiovascular disease and diabetes later in life $(13,14)$ but the question is whether there is a metabolic syndrome in the mother before and during pregnancy. Most studies have assessed the relationship between metabolic syndrome components such as hypertension, obesity, diabetes, dyslipidemia, and adverse outcomes in pregnancy (6). But few studies have been conducted on metabolic syndrome and preterm labor which are inconsistent. In the study by Grieger et al., the metabolic syndrome of the mother at the onset of pregnancy had no significant relationship with low birth weight and preterm delivery (9). But in the study by Chatzi et al., the risk of preterm delivery in mothers with metabolic syndrome increased approximately threefold (6).

Considering the lack of confirmatory evidence on the association between the metabolic syndrome and preterm labor or PPROM, especially in Iran, we decided to assess metabolic syndrome in mid-pregnancy and determine their associations with the occurrence of preterm delivery and preterm premature rupture of membranes.

\section{Methods}

This prospective cohort study was performed on 203 pregnant women referred to Niloo and Akbarabadi laboratories in Tehran, from August 2013 through June 2014.

Participants were 18-45 year old pregnant Iranian women with singleton pregnancies, who had been referred to these laboratories for routine gestational diabetes screening test with 50 gr glucose challenge test (GCT), between the $24^{\text {th }}-28^{\text {th }}$ weeks of gestation. Women who were at high risk for preterm delivery due to underlying medical conditions (e.g., chronic hypertension or diabetes) were excluded.

After explaining the study details and obtaining written consent from the women participants, they were enrolled in the study. At the entry, maternal characteristics such as age, parity, educational level, height, weight and pre-pregnancy body mass index (BMI), blood pressure, nutritional complements consumed during pregnancy, family history of diabetes, hypertension, and dyslipidemia were documented. 
During the following weeks, venous samples were obtained from the participants in fasting status to measure serum total cholesterol, low density lipoprotein cholesterol (LDL-C), high density lipoprotein cholesterol (HDL-C), and triglyceride (TG) levels.

As there is no definition of metabolic syndrome in pregnancy, we modified the Metabolic Syndrome Diagnosis Criteria of NCEP-ATP III $(15,16)$, in which the presence of 3 or more of the following criteria sets the diagnosis of MetS: Central obesity, waist circumference $>88 \mathrm{~cm}$ or BMI $>30 \mathrm{~kg} / \mathrm{m} 2$, triglycerides $>$ $150 \mathrm{mg} / \mathrm{dl}, \mathrm{HDL}-\mathrm{C}<50 \mathrm{mg} / \mathrm{dl}$, systolic Blood Pressure $>130$, diastolic BP $>85 \mathrm{mmHg}$, and/or fasting blood glucose (FBS) $>105 \mathrm{mg} / \mathrm{dl}$. Since waist circumference increases naturally in pregnancy and is thus inapplicable in this study, we used pre-pregnancy $\mathrm{BMI}>30 \mathrm{~kg} / \mathrm{m} 2$ instead of waist circumference. FBS was also replaced by impaired GCT results (glucose intolerance). Thus, our diagnosis of MetS in pregnancy was based on the presence of 3 or more of the following criteria: Pre-pregnancy BMl $\geq 30 \mathrm{~kg} / \mathrm{m} 2$, $\mathrm{GCT} \geq 140 \mathrm{mg} / \mathrm{dl}$, systolic blood pressure $\geq 130 \mathrm{mmhg}$ or diastolic blood pressure $\geq 85 \mathrm{mmHg}$ (taken twice, at least six hours apart), plasma triglyceride levels $\geq 150 \mathrm{mg} / \mathrm{dl}$, and HDL-C levels $\leq 50 \mathrm{mg} / \mathrm{dl}$.

All mothers went through routine prenatal care and were followed up to delivery. Preterm delivery and PPROM were defined as delivery or rupture of membranes of less than or equal to 37 weeks of pregnancy respectively.

All data were registered and analysed by SPSS software V.20, using chi-square and bivariate logistic regression analysis; $p$-value of less than 0.05 were considered statistically significant.

This research was approved by the Ethical Committee of the Faculty of Medical Sciences in Tarbiat Modares University, Tehran, Iran.

\section{Results}

A total of 203 pregnant women were enrolled in the study. As many as 18 (8.9\%) preterm deliveries and 10(4.9\%) PPROM cases occurred among the study subjects. Demographic and reproductive characteristics of the study participants are demonstrated and compared between the 2 study groups (preterm and term deliveries) in table 1. Using the Independent Student T-Test and Chi-Square tests, no statistically significant differences were detected between the two groups (Table 1). The only different variable between the two groups, as expected, was gestational age at delivery (34.11 vs. 38.71 weeks for preterm and term deliveries respectively).

MetS was detected in $10(4.9 \%)$ study participants. High cholesterol $(\geq 200 \mathrm{mg} / \mathrm{dl})$ and TG $(\geq 150 \mathrm{mg} / \mathrm{dl})$ levels were observed in 75.4 and $82.8 \%$ of participants respectively. Metabolic syndrome, together with its components, and cholesterol and LDL levels were compared between preterm labor and term deliveries by Fisher's Exact Test (Table 2). The only statistically significant differences between the two groups were in the impaired GCT results and high LDL levels, both occurring more in the preterm group [( $61.1 \%$ vs. $37.3 \%)$ and (55.6\% VS $32.4 \%)$ respectively]. 
Metabolic syndrome, together with its components, and cholesterol and LDL levels were compared between PPROM versus term deliveries by Fisher's Exact Test which revealed no statistically significant differences between the two groups (Table 3 ).

To adjust for confounding variables, we used Logistic Regression Analysis to evaluate some potential factors affecting preterm labor, i.e. number of pregnancies, mothers' education, use of multivitamins during pregnancy, history of preterm labor, and metabolic syndrome together with its components (Table 4). Additionally, this analysis was performed for the PPROM cases (Table 4). Logistic Regression showed that HDL levels and hypertension had significant effects on the occurrence of preterm deliveries, with lower levels of $\mathrm{HDL}$ and hypertension increasing the occurrence [(OR:0.952, 95\% Cl: 0.910_0.995), and (OR:1.629, 95\%Cl: 1.554_1.709), respectively. Regarding PPROM, only mothers' age had a significant impact; as the aged increased, PPROM occurrence decreased (OR: 0.796, 95\%Cl: 0.661_0.960).

\section{Discussion}

In this prospective cohort study of 203 Iranian pregnant women in mid-pregnancy, $8.9 \%$ of deliveries were preterm, and prevalence of MetS was $4.9 \%$. This study showed that some of components of MetS related with preterm labor.

This study showed that impaired glucose tolerance (impaired GCT results) was significantly associated with preterm labor. A Turkish study found that the incidence of preterm labor was not altered by GDM status (17), but most studies have suggested that high glucose levels are associated with preterm labor. Yun et al, in Korea, showed that glucose intolerance and gestational diabetes (GD) were risk factors for preterm labor (18). In addition, Basirat et al. reported that the prevalence of PROM and preterm labor, in Iran, was higher in pregnant women with abnormal GCT results (19). Diverse mechanisms, such as inflammation, infection, stress and some immunologic mechanisms might explain this situation (20).

In this study, lower levels of HDL-C and elevated levels of LDL-C were also significantly associated with preterm labor. These findings are consistent with the results of some other studies (20-22). Some metabolic factors related with inflammation may be associated with increased risk of spontaneous preterm labor. Maternal hyperlipidemia may increase oxidative stress in the fetus, resulting in damage of the umbilical vessel wall and disruption of normal placentation $(23,24)$. Increasing evidence suggests that elevated plasma lipids may induce endothelial dysfunction. Interaction of maternal components such as neutrophils and oxidation susceptible lipids with placental cells engenders a forwarding cycle of oxidative stress (24). Oxidative stress produces free radicals and lipid peroxidase (25).

In this study, a significant relationship was observed between gestational hypertension and preterm birth. Leda Ghatzi et al., assessed the association between metabolic syndrome components and the risk of preterm birth in Greece, and their findings showed that the most significant risk factor was hypertension (6). Catov et al. suggested that chronic hypertension, diabetes, body mass index, and age were related to the risk of term and preterm SGA births (26). Gilbert reported that mothers with chronic hypertension are at risk of various neonatal morbidities such as low birth weight and prematurity (27). In general, women 
with hypertension may have an inadequate vascular response and may suffer from a defect in endothelial wall and also abnormal placentation; on the other hand, gestational hypertension, independent of maternal obesity and metabolic disorders, is associated with insulin resistance and dyslipidemia.

In this study, no significant relationship was observed between metabolic syndrome and preterm birth and PPROM. Similarly, in a study by Baliutavičienè et al., gestational age in women who had three components of metabolic syndrome (impaired glucose tolerance, obesity, and hypertension) with healthy women was not different (28). Furthermore, in the study by Grieger et al., diagnosis of MetS was not associated with increased risk at lower gestational ages (9). However, in the study by Lei et al., metabolic abnormalities in pregnancy were associated with adverse pregnancy such as preterm labor (29). The reason for the difference in the results of these studies is that there is no single definition for the metabolic syndrome in pregnancy and different measurements have been carried out to diagnose the metabolic syndrome.

This study provides a new insight into the metabolic syndrome and its components in mid-pregnancy (24th-28th weeks of gestation) and any possible association with preterm birth; To our best knowledge, no such investigation has hitherto been conducted in Iran, measuring and evaluating precisely all these components in addition to lipid profiles in mid-pregnancy and following subjects up to delivery.

A major limitation was the lack of a standard definition for gestational metabolic syndrome. Thus, we used a pregnancy-modified version of NCEP-ATP III definition of metabolic syndrome for a general population, which needs further investigations to be confirmed. Also, the sample size of this study is not large enough to draw definitive conclusions. Further research is needed with larger samples/cohorts for clarification and confirmation of these associations. The protective effect of metabolic syndrome observed on preterm birth needs further investigations too.

\section{Conclusion}

To conclude, our findings can be used to identify pregnancies at higher risk of preterm deliveries earlier, and to implement appropriate measures to prevent them.

\section{Abbreviations}

MetS: Metabolic Syndrome

PPROM: Preterm Premature Rupture Of Membranes

GCT: Glucose Challenge Test

LDL-C: Low-Density Lipoprotein Cholesterol

HDL-C: High -Density Lipoprotein Cholesterol 
TG: Triglyceride

BP: Blood Pressure

WHO: World Health Organization

BMl: Body Mass Index

FBS: Fasting Blood Glucose

\section{Declarations}

\section{Ethics approval and consent to participate}

Informed written consent was obtained from all participants.

\section{Consent for publication}

consent for publication was obtained from all participants.

\section{Availability of data and materials}

The datasets used and/or analysed during the current study are available from the corresponding author on reasonable request.

\section{Competing interests}

The authors declare that they have no competing interests

\section{Funding}

This study was performed as the thesis project for an M.Sc. degree in midwifery in Faculty of Medical Sciences, Tarbiat Modares University, Tehran, Iran.

\section{Authors' contributions}

$S N$ : Project development, Data Collection, Manuscript writing

LM: project administration, writing-review and editing, supervision

HSData Collection, Manuscript writing 


\section{Acknowledgements}

We are grateful to the participants in the study.

\section{References}

1.Reaven G. Role of insulin resistance in human disease. Diabetes. 1988;37(12):1595-607.

2.Sinclair K, Bogart A, Buchwald D, Henderson J. The prevalence of metabolic syndrome and associated risk factors in Northern Plains and Southwest American Indians. Diabetes care. 2011;34(1):118-20.

3.Souza LD, Berger H, Retnakaran R, Maguire J, Nathens A, Connelly P, et al. First-Trimester Maternal Abdominal Adiposity Predicts Dysglycemia and Gestational Diabetes Mellitus in Midpregnancy. Diabetes Care. 2016;39(1):61-4.

4.Lim S, Shin H, Song J, Kwak S, Kang S, Yoon JW, et al. Increasing prevalence of metabolic syndrome in Korea: the Korean National Health and Nutrition Examination Survey for 1998-2007. Diabetes Care. 2011;34(6):1323-8.

5.Azimi-Nezhad M, Herbeth B, Siest G, Dadé S, Ndiaye N, Esmaily H, et al. High prevalence of metabolic syndrome in Iran in comparison with France: what are the components that explain this?. Metab Syndr Relat Disord. 2012 10(3):181-8.

6.Chatzi L, Plana E, Daraki V, Karakosta P, Alegkakis D, Tsatsanis C. Metabolic syndrome in early pregnancy and risk of preterm birth. American journal of epidemiology. 2009;170(7):829-36.

7.Roberts C. IFPA Award in Placentology Lecture: complicated interactions between genes and the environment in placentation, pregnancy outcome and long term health. Placenta. 2010;31:47-53.

8. Wiznitzer A, Mayer A, Novack V, Sheiner E, Gilutz H, Malhotra A. Association of lipid levels during gestation with preeclampsia and gestational diabetes mellitus: a population-based study. Am J Obstet Gynecol. 2009;201(482):1-8.

9.Grieger J, Bianco-Miotto T, Grzeskowiak L, Leemaqz S, Poston L, McCowan L, et al. Metabolic syndrome in pregnancy and risk for adverse pregnancy outcomes: A prospective cohort of nulliparous women. PLoS Med. 2018;4(15).

10.Mu P. Maternal role transition experiences of women hospitalized with PROM: a phenomenological study. Int J Nurs Stud. 2004;41(8):825-32. 
11.Nagano N, Okada T, Yonezawa R, Yoshikawa K, Fujita H, Usukura Y, et al. Early postnatal changes of lipoprotein subclass profile in late preterm infants. Clin Chim Acta. 2012;18(413):109-12.

12.Noor S, Nazar A, Bashir R, Sultana R. Prevalance of PPROM and its outcome. J Ayub Med Coll Abbottabad. 2007;19(4):14-7.

13.James-Todd T, Wise L, Boggs D, Rich-Edwards J, Rosenberg L, Palmer J. Preterm birth and subsequent risk of type 2 diabetes in black women. Epidemiology. 2014;25(6):805-10.

14.Catov J, Wu C, Olsen J, Sutton-Tyrrell K, Li J, Nohr E. Early or recurrent preterm birth and maternal cardiovascular disease risk. Ann Epidemiol. 2010;20:604-9.

15.Bartha J, González-Bugatto F, Fernández-Macías R, González-González N, Comino-Delgado R, HervíasVivancos B. Metabolic syndrome in normal and complicated pregnancies. Eur J Obstet Gynecol Reprod Biol. 2008;137(2):178-84.

16.Alexander C, Landsman P, Teutsch S, Haffner S. Third National Health and Nutrition Examination Survey (NHANES III); National Cholesterol Education Program (NCEP). NCEP-defined metabolic syndrome, diabetes, and prevalence of coronary heart disease among NHANES III participants age 50 years and older. Diabetes. 2003 52(5):1210-4.

17.Biri A, Korucuoglu U, Ozcan P, Aksakal N, Turan O, Himmetoglu O. Effect of different degrees of glucose intolerance on maternal and perinatal outcomes. J Matern Fetal Neonatal Med. 2009 22(6):473-8.

18.Yun S, Han S, Lee S, Jung Y, Kim E. Comparison of Obstetric and Neonatal Outcomes According to Oral Glucose Challenge Test in Korean Pregnant Women. Korean Journal of Perinatology. 2013;24(3):180-6.

19.Basirat Z, Asnafi N, Kashifard M. Correlation between abnormal glucose challenge test and pregnancy outcomes. Journal Of Reproductive and Infertility 2010;11(2):113-19.

20.Catov J, Bodnar L, Ness R, Barron S, Roberts J. Inflammation and dyslipidemia related to risk of spontaneous preterm birth. Am J Epidemiol. 2007;166(11):1312-9.

21. Hotamisligil G. Inflammation and metabolic disorders. Nature. 2006;14(444):860-7.

22.Catov J, Bodnar L, Kip K, Hubel C, Ness R, Harger G, et al. Early pregnancy lipid concentrations and spontaneous preterm birth. Am J Obstet Gynecol. 2007;197(6):1-7.

23.Vrijkotte T, Krukziener N, Hutten B, Vollebregt K, Eijsden Mv, Twickler M. Maternal lipid profile during early pregnancy and pregnancy complications and outcomes: the ABCD study. J Clin Endocrinol Metab. 2012 97(11):3917-25. 
24.Siahanidou T, Margeli A, Kappis A, Papassotiriou I, Mandyla H. Circulating visfatin levels in healthy preterm infants are independently associated with high-density lipoprotein cholesterol levels and dietary long-chain polyunsaturated fatty acids. Metabolism. 2011;60(3):389-93.

25. Hubel C. yslipidemia, iron, and oxidative stress in preeclampsia: assessment of maternal and fetoplacental interactions. Semin Reprod Endocrinol. 1998;16(1):75-92.

26.Catov J, Nohr E, Olsen J, Ness R. Chronic hypertension related to risk for preterm and term small for gestational age births. Obstet Gynecol. 2008 112(2):290-6.

27.Gilbert W, Young A, Danielsen B. Pregnancy outcomes in women with chronic hypertension: a population-based study. J Reprod Med. 2007 52(11):1046-51.

28.Baliutavičienè D, Buinauskienè J, Petrenko V, Danytè E, Žalinkevičius R. Gestational diabetes, obesity, and metabolic syndrome diagnosed during pregnancy. Metab Syndr Relat Disord. 2012;10(3):214-7.

29.Lei Q, Niu J, Lv L, Duan D, Wen J, Lin X, et al. Clustering of metabolic risk factors and adverse pregnancy outcomes: a prospective cohort study. Diabetes Metab Res Rev. 2016 32(8):835-42.

\section{Tables}

Table 1: Comparison of the demographic and reproductive characteristics of participants (n $=203)$ 


\begin{tabular}{|c|c|c|c|}
\hline \multirow[t]{2}{*}{ Characteristics } & \multicolumn{3}{|c|}{$\begin{array}{c}\text { Study Group } \\
(\mathrm{n}=203)\end{array}$} \\
\hline & Preterm delivery $(n=18)$ & Term delivery $(n=185)$ & p-value \\
\hline Maternal age (years) & $30.22 \pm 5.31$ & $29.35 \pm 4.56$ & ${ }^{1} .450$ \\
\hline Years of education & $13.22 \pm 3.82$ & $13.38 \pm 4.30$ & 1.878 \\
\hline BMI (kg/m2) & $24.10 \pm 4.30$ & $24.16 \pm 3.2$ & 1.947 \\
\hline Gestational age at labor (weeks) & $34.11 \pm 2.67$ & $38.71 \pm 0.977$ & $1<0.001$ \\
\hline \multicolumn{4}{|l|}{ Number of pregnancies } \\
\hline 1 & $10(55.6 \%)$ & $109(58.9 \%)$ & 2.782 \\
\hline$\geq 2$ & $8(44.4 \%)$ & $76(41.1 \%)$ & \\
\hline \multicolumn{4}{|l|}{ Job(Occupation) } \\
\hline Housewife & $11(61.1 \%)$ & $115(62.2 \%)$ & 2.930 \\
\hline 0ccupied(Employed) & $7(38.9 \%)$ & $70(37.8 \%)$ & \\
\hline \multicolumn{4}{|l|}{ Type of delivery } \\
\hline NVD & $5(27.8 \%)$ & $43(23.2 \%)$ & ${ }^{2} .666$ \\
\hline $\mathrm{C} / \mathrm{S}$ & $13(72.2 \%)$ & $142(76.8 \%)$ & \\
\hline \multicolumn{4}{|c|}{ Use of supplements during pregnancy } \\
\hline Folic acid & $15(83.3 \%)$ & $132(71.4 \%)$ & 2.782 \\
\hline Iron & $10(55.6 \%)$ & $131(70.8 \%)$ & 2.180 \\
\hline Calcium & $7(38.9 \%)$ & $83(44.9 \%)$ & 2.626 \\
\hline Multivitamins & $11(61.1 \%)$ & $114(61.6 \%)$ & 2.966 \\
\hline
\end{tabular}


.Data are defined as mean \pm SD or n (\%), as appropriate

BMI: body mass index; C/S: caesarian section; NVD: natural vaginal delivery

1. ${ }^{1}$. Based on Independent Student T-Test

2. ${ }^{2}$. Based on Chi-Square Test

Table 2: Distribution of metabolic syndrome, its components, and lipid profiles among preterm and term deliveries

\begin{tabular}{|c|c|c|c|c|c|c|c|c|}
\hline \multirow[t]{2}{*}{ Study group } & $\mathrm{BP} \geq 130 / 85 \mathrm{mmh}$ & $\mathrm{BMI} \geq 30 \mathrm{~kg} / \mathrm{m} 2$ & $\begin{array}{l}\mathrm{GCT} \geq 140 \\
\mathrm{mg} / \mathrm{dl}\end{array}$ & $\begin{array}{l}\mathrm{TG} \geq 150 \\
\mathrm{mg} / \mathrm{dl}\end{array}$ & $\begin{array}{l}\mathrm{LDL} \geq 130 \\
\mathrm{mg} / \mathrm{dl}\end{array}$ & $\begin{array}{l}\mathrm{HDL} \leq 50 \\
\mathrm{mg} / \mathrm{dl}\end{array}$ & $\begin{array}{l}\text { Cholesterol } \geq 200 \\
\mathrm{mg} / \mathrm{dl}\end{array}$ & MetS \\
\hline & N (\%) & (\%) $\mathrm{N}$ & (\%) $\mathrm{N}$ & (\%) $\mathrm{N}$ & (\%) $\mathrm{N}$ & (\%) $\mathrm{N}$ & (\%) $\mathrm{N}$ & (\%) $\mathrm{N}$ \\
\hline $\begin{array}{l}\text { Preterm } \\
\text { delivery } \quad(n=18)\end{array}$ & $\begin{array}{c}1 \\
(5.6)\end{array}$ & $\begin{array}{c}1 \\
(5.6)\end{array}$ & $\begin{array}{c}11 \\
(61.1)\end{array}$ & $\begin{array}{c}16 \\
(88.9)\end{array}$ & $\begin{array}{c}10 \\
(55.6)\end{array}$ & $\begin{array}{c}0 \\
(0.00)\end{array}$ & $\begin{array}{c}16 \\
(88.9)\end{array}$ & $\begin{array}{c}2 \\
(11.1)\end{array}$ \\
\hline $\begin{array}{l}\text { Term delivery } \\
(\mathrm{n}=185)\end{array}$ & $\begin{array}{c}14 \\
(7.6)\end{array}$ & $\begin{array}{c}11 \\
(5.9)\end{array}$ & $\begin{array}{c}69 \\
(37.3)\end{array}$ & $\begin{array}{c}152 \\
(82.2)\end{array}$ & $\begin{array}{c}60 \\
(32.4)\end{array}$ & $\begin{array}{c}4 \\
(2.2)\end{array}$ & $\begin{array}{c}137 \\
(74.1)\end{array}$ & $\begin{array}{c}8 \\
(4.3)\end{array}$ \\
\hline $\begin{array}{l}p \text {-value } \\
\text { (fishers' exact } \\
\text { test) }\end{array}$ & 1.000 & 1.000 & 0.016 & 0.744 & 0.046 & 1.000 & 0.251 & 0.288 \\
\hline
\end{tabular}

BP: Blood pressure; BMI: body mass index; GCT: glucose challenge test; TG: triglycerides;

LDL: low density lipoprotein

HDL: high density lipoprotein; MetS: metabolic syndrome

Table 3: Distribution of metabolic syndrome, its components, and lipid profisle among PPROM and term deliveries 


\begin{tabular}{|c|c|c|c|c|c|c|c|c|}
\hline \multirow[t]{2}{*}{ Study group } & $\mathrm{BP} \geq 130 / 85 \mathrm{mmhg}$ & $\mathrm{BMI} \geq 30 \mathrm{~kg} / \mathrm{m} 2$ & \begin{tabular}{|l|}
$\mathrm{GCT} \geq 140$ \\
$\mathrm{mg} / \mathrm{dl}$
\end{tabular} & $\begin{array}{l}\mathrm{TG} \geq 150 \\
\mathrm{mg} / \mathrm{dl}\end{array}$ & $\begin{array}{l}\mathrm{LDL} \geq 130 \\
\mathrm{mg} / \mathrm{dl}\end{array}$ & $\begin{array}{l}\mathrm{HDL} \leq 50 \\
\mathrm{mg} / \mathrm{dl}\end{array}$ & $\begin{array}{l}\text { Cholesterol } \geq 200 \\
\mathrm{mg} / \mathrm{dl}\end{array}$ & MetS \\
\hline & (\%) $\mathrm{N}$ & (\%) $\mathrm{N}$ & (\%) $\mathrm{N}$ & (\%) $\mathrm{N}$ & $(\%) \mathrm{N}$ & (\%) $\mathrm{N}$ & (\%) $\mathrm{N}$ & \begin{tabular}{|c}
$\mathrm{N}$ \\
$(\%)$
\end{tabular} \\
\hline $\begin{array}{l}\text { PPROM } \\
(n=10)\end{array}$ & $\begin{array}{c}2 \\
(20)\end{array}$ & $\begin{array}{c}0 \\
(0.0)\end{array}$ & $\begin{array}{c}6 \\
(60)\end{array}$ & $\begin{array}{c}8 \\
(80)\end{array}$ & $\begin{array}{c}6 \\
(60)\end{array}$ & $\begin{array}{c}0 \\
(0.00)\end{array}$ & $\begin{array}{c}9 \\
(90)\end{array}$ & $\begin{array}{c}1 \\
(10)\end{array}$ \\
\hline $\begin{array}{c}\text { Term } \\
\text { delivery } \\
(\mathrm{n}=185)\end{array}$ & $\begin{array}{c}13 \\
(6.7)\end{array}$ & $\begin{array}{c}12 \\
(6.2)\end{array}$ & $\begin{array}{c}74 \\
(40.4)\end{array}$ & $\begin{array}{c}160 \\
(82.9)\end{array}$ & $\begin{array}{c}64 \\
(33.2)\end{array}$ & $\begin{array}{c}4 \\
(2.1)\end{array}$ & $\begin{array}{c}144 \\
(74.6)\end{array}$ & $\begin{array}{c}9 \\
(4.7)\end{array}$ \\
\hline $\begin{array}{c}\text { P-value } \\
\text { fishers') } \\
\text { (exact test }\end{array}$ & 0.162 & 1.000 & 0.088 & 0.684 & 0.096 & 1.000 & 0.456 & 0.464 \\
\hline
\end{tabular}

* PPROM: preterm premature rupture of membranes

Table 4: Logistic regression analysis of potential effective factors on preterm labor and PPROM 


\begin{tabular}{|c|c|c|c|c|c|c|}
\hline \multirow[t]{2}{*}{ Variables } & \multicolumn{3}{|c|}{ Preterm labor } & \multicolumn{3}{|c|}{ PPROM } \\
\hline & $\begin{array}{l}\text { Odds } \\
\text { Ratio }\end{array}$ & $\begin{array}{c}\text { 95\% Confidence } \\
\text { Interval } \\
\end{array}$ & $\begin{array}{c}\text { p- } \\
\text { value }\end{array}$ & $\begin{array}{l}\text { Odds } \\
\text { Ratio }\end{array}$ & $\begin{array}{c}\text { 95\% Confidence } \\
\text { Interval } \\
\end{array}$ & $\mathrm{p}$-value \\
\hline Age (years) & .988 & .863_1.131 & .860 & .796 & $.661 \_.960$ & .017 \\
\hline Number of pregnancies & 1.258 & $.608 \_2.603$ & .536 & 1.372 & $.691 \_3.797$ & .267 \\
\hline Education (years) & 1.118 & $.970 \_1.287$ & .123 & .998 & $.813 \_1.226$ & .987 \\
\hline $\begin{array}{c}\text { History of preterm } \\
\text { delivery }\end{array}$ & .136 & $.015 \_1.202$ & .073 & 6.452 & $.358 \_116.30$ & .206 \\
\hline $\begin{array}{l}\text { Multivitamin } \\
\text { consumption } \\
\end{array}$ & .851 & .253_2.857 & .794 & 1.41 & $.286 \_7.02$ & .670 \\
\hline $\begin{array}{c}\text { Impaired glucose } \\
\text { challenge test }\end{array}$ & .105 & $.103 \_1.241$ & .105 & 4.320 & .739_25.23 & .104 \\
\hline Hypertension & 162.92 & $1.554 \_1.709$ & .032 & 4.809 & .270_85.78 & .285 \\
\hline Metabolic syndrome & .027 & .101_1.982 & .249 & .206 & $.003 \_12.96$ & .454 \\
\hline Cholesterol (mg/dl) & 1.013 & $.992 \_1.035$ & .231 & .993 & $.968 \_1.018$ & .577 \\
\hline $\mathrm{HDL}(\mathrm{mg} / \mathrm{dl})$ & .952 & $.910 \_995$ & .030 & 1.020 & .966_1.076 & .476 \\
\hline $\mathrm{LDL}(\mathrm{mg} / \mathrm{dl})$ & .981 & $.957 \_1.005$ & .119 & 1.019 & .988_1.050 & .237 \\
\hline Triglycerides (mg/dl) & .993 & $.984 \_1.001$ & .088 & 1.006 & $.995 \_1.016$ & .292 \\
\hline $\begin{array}{c}\text { Body mass index } \\
\left(\mathrm{kg} / \mathrm{m}^{2}\right)\end{array}$ & 1.085 & $.916 \_1.285$ & .345 & .907 & $.731 \_1.125$ & .374 \\
\hline
\end{tabular}

